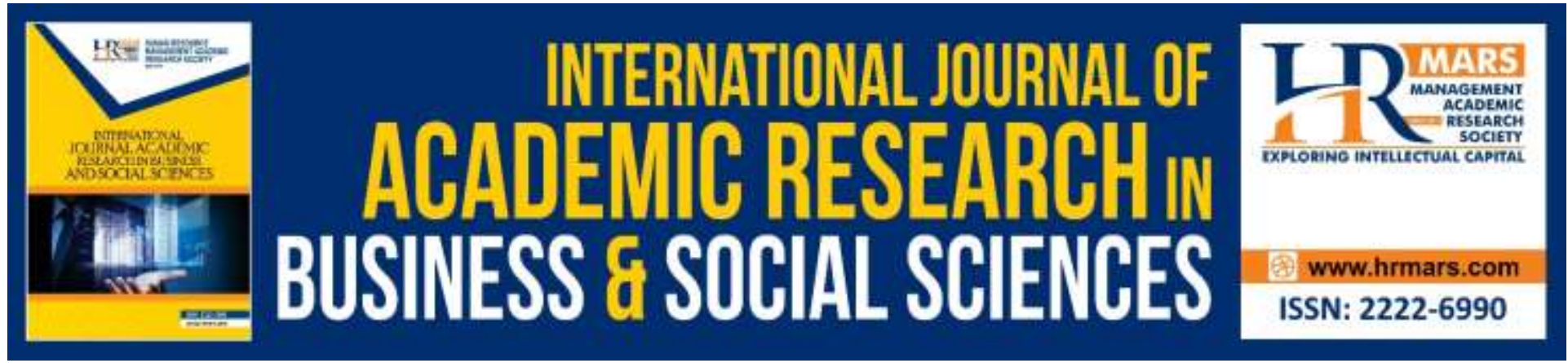

\title{
Consumer Purchase Regret: A Systematic Review
}

\section{Muhammad Arslan Sarwar, Zainudin Awang, Muhammad Danish Habib}

To Link this Article: http://dx.doi.org/10.6007/IJARBSS/v9-i9/6307

DOI: $10.6007 /$ IJARBSS/v9-i9/6307

Received: 06 July 2019, Revised: 10 August 2019, Accepted: 30 August 2019

Published Online: 23 September 2019

In-Text Citation: (Sarwar, Awang, Habib, 2019)

To Cite this Article: Sarwar, M. A., Awang, Z., Habib, M. D. (2019). Consumer Purchase Regret: A Systematic Review. International Journal of Academic Research in Business and Social Sciences. 9(9), 403- 425.

Copyright: (c) 2019 The Author(s)

Published by Human Resource Management Academic Research Society (www.hrmars.com) This article is published under the Creative Commons Attribution (CC BY 4.0) license. Anyone may reproduce, distribute, translate and create derivative works of this article (for both commercial and non-commercial purposes), subject to full attribution to the original publication and authors. The full terms of this license may be seen at: http://creativecommons.org/licences/by/4.0/legalcode

Vol. 9, No. 9, 2019, Pg. 403 - 425

Full Terms \& Conditions of access and use can be found at http://hrmars.com/index.php/pages/detail/publication-ethics 


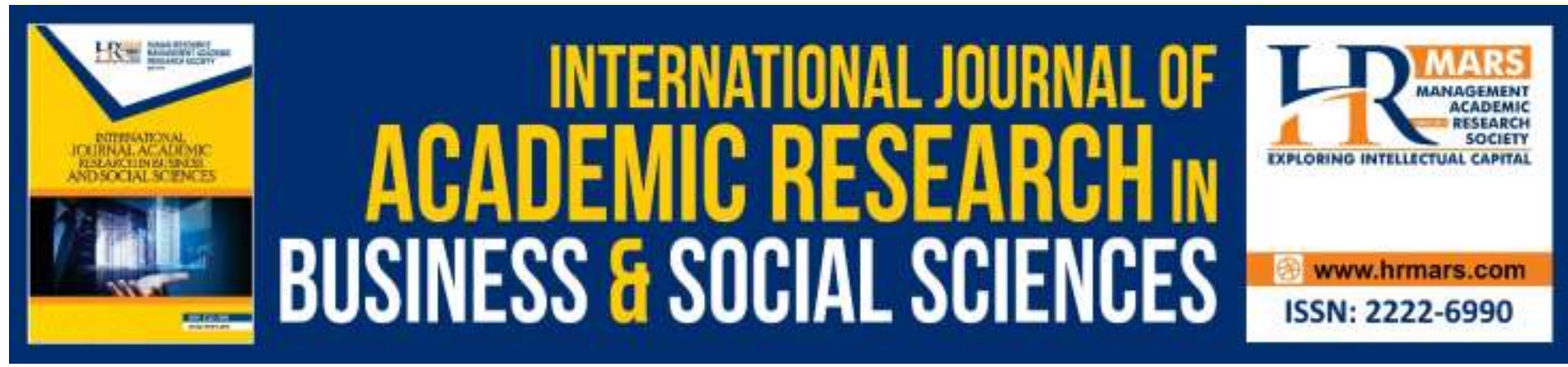

\title{
Consumer Purchase Regret: A Systematic Review
}

\author{
${ }^{1}$ Muhammad Arslan Sarwar, ${ }^{2}$ Zainudin Awang, ${ }^{3}$ Muhammad \\ Danish Habib \\ ${ }^{1,2}$ Faculty of Economics \& Management Sciences, University Sultan Zainal Abidin, Malaysia \\ ${ }^{1,3}$ Faculty of Management \& Administrative Sciences, University of Gujrat, Pakistan
}

\begin{abstract}
This study aims to highlight and summarize the systematic review to analyze the significant factors in consumer purchase regret." Specifically, the study analyzes: a) the prevailing definition of consumer purchase regret throughout the period; b) theoretical lens, through which this concept has been explored; c) key contributions of Consumer purchase regret; and d) Methods of research used to test sustainable consumption. Consumer purchase regret is the central interest ofemotions in the current article. Academics and marketers are constantly concerned with the increased importance of consumer behavioral issues and their elevation towards an important agenda for purchase regret. In addition, it has also been recognized as a key driver of innovation by marketers. The novelty of this article is based on the systematic literature review of theories and empirical findings concerning consumer purchase regret in last few years. The possible effects of purchase regret on consumer behavior were discussed and also considered the anticipation of regret influencing on decision making.

In order to review current regret conceptions in accordance with Denyer and Tranfield's instructions, the five-step approach to SLR was followed after a comprehensive database search and applying inclusion criteria, 15 research articles were incorporated for this systematic review. The core part of the paper discusses the specific CPR methodology used in this study and presents the review findings and discusses them. Finally, future developments are recommended in the promising field and the overall contribution in addressing critical challenges for CPR. The results of the review showed that the concept of consumer purchase regret has changed over time as consumer behavioral changes progresses. In addition, the study revealed that cross-sectional designs based on the survey methods taking into account certain subpopulations are widely used in existing research methodologies. Future studies on consumer purchase regret can be focused more on exploring additional issues regardingthe antecedents and critical challenges faced by both marketers and consumers in the developing countries.
\end{abstract}

Keywords: Consumer Purchase Regret, Systematic Literature Review, Decision Making, Cognitive Process, Consumer Behavior. 


\section{Introduction}

The feelings of regret havebeen characterized as the adverse cognitive based effect that individuals encounter while realizing or envisioning that their present circumstance would have been better if they had acted in a different manner (Zeelenberg, 1999). According to Zeelenberg regret is related with consideration, sentiments, and desired actions, for example, a feeling of drowning, crying over split milk, thinking about a missing chance, feeling of starting again the same situation to improve the consequences, doing something differently with a second chance (Zeelenberg and Pieters, 1999).According to Landman (1993), "regret is defined as a more or less painful judgment and state of feeling sorry for misfortunes, limitations, losses, shortcomings, transgressions, or mistakes." Such type of consumer purchase regret can cause dissatisfaction (Zeelenberg and Pieters, 1999,2004; Tsiros and Mittal, 2000) and service switching (Zeelenberg and Pieters, 1999,2004) changing consumers' subsequent buying behavior (Cooke et al., 2001; Greenleaf, 2004; Lemon et al., 2002; Simonson, 1992).

Regardless of theresearch work concerning the occurrence of regret andits consequences, the antecedents of regret are still not well known. Up to the date the regret response has been experimentally manipulated by most regret studies using recall or situations abouta poorbrand or product performance (Inman and Zeelenberg,2002; Tsiros and Mittal, 2000; Zeelenberg and Pieters, 1999,2004), toinspect regret's effects. So the causes of regret need to be explored further.Despite the recent researches made in last some years in consumer purchase regret (herein referred as CPR) research (Liao et al., 2016; Gabler et al., 2017; Davvetas et al., 2017) The search for answers on how customer behavior can be influenced more effectively by purchase regret remains an ongoing and critical issue. Debates on future CPR directions usually refer to some key challenges.

The first crucial challenge addresses the issue of how regret arises and what can be the possible antecedents and consequences of CPR, and how they play a role indecision making and consumer behavior. The second challenge emerges from the fact that how CPR can be evaluated without biases; as positive feelings are easy to judge and assess but harmful feelings are hard to analyze. The third one refers to a needfor comprehensive, systematic overviews of CPR findings on consumer behavior (as the behavior of consumers is changing rapidly).

Given this, it is essential for CPR to pursue and combine a basis of evidence of practical approaches to go through and advance the literature on sustainable consumer behavior. The research described in this paper seeks to address these critical challenges in the context of a particular issue.

For this reason, we have carried out a systematic literature review (herein referred as SLR).

As per the directions of Denyer and Tranfield (2009), the five-step method for conducting an SLR was followed: "(1) formulate one or more research questions; (2) locate studies; (3) select and evaluate studies; (4) analyze and synthesize studies; and (5) report and use the results". The main research issues underlying this study are:

$R Q$ 1: How many research studies available on Consumer Purchase Regret?

$R Q$ 2: How have these studies been carried out?

$R Q$ 3: What are their outcomes? 
We first provide some theoretical background on CPR as a basis for responding to the research questions outlined. The next part of the manuscript describes the specific CPR methodology used in this study and presents the findings of the review and discusses them. Finally, we recommend the future improvement of this promising research area and its overall contribution to addressing critical challenges for CPR.

\section{Method: Systematic Literature Review}

To address the objective of this research, we carried out a systematic literature review (SLR), which is a rigorous method to provide an overview of a particular research field and the results it has produced. This approach has a growing trend for past years due to some reasons. SLRs address the orientation issue in light of the fast-growing body of publications that can no longer be overlooked (Ridley, 2012).

A widely accepted definition of an SLR refers to "a systematic, explicit, and reproducible method for identifying, evaluating and synthesizing the existing body of completed and recorded work produced by researchers, scholars and practitioners" (Fink, 2009). According to this the most significant concept about the SLR method is that it's not just a simple introductory part of a research study, but relatively, "in itself a research study, addressing research questions and using the literature as data to be coded, analyzed and synthesized to reach overall conclusions" (Ridley, 2012).

The core purpose in carrying out an SLR is to contribute to the development of a broader research outline so we will explore whathas been already established in existing empirical studies and what can be done for future researches.

During screening phase, every article was read and selected based on the inclusion criterion, as the focus of study was consumer purchase regret, issues, and related outcomes. For an article to be included in the study, critical issues in consumer purchase regret were the core concepts of the research objectives focusing on some significant aspects. All types of articles whether quantitative and qualitative, were included to get a comprehensive picture of the previous literature in the context of consumer purchase regret. The main articles consisting the basic key words in purchase regret were highly focused. Few articles were excluded from the study, as the theme were studied differently. In short, those articles were selected which were published during year 2015-2018 in highly indexed journals of Science Direct and SCOPUS; and demonstrate significant antecedents, trends, and behavioral intentions in consumer purchase regret. All the selected articles were organized in a structured matrix with author name, constructs studies, methods and tools based on certain mechanism as shown Table 1.

\section{Data Collection}

For this SLR the data was gathered in three stages, and each progression of information gathered was inserted in a particular phase of the iterative procedure of screening publications (see Fig. 1). To do recognized and quality oriented research our SLR centered on peer-reviewed journal articles which were published in recognized journals.

The startup of collecting data for relevant research articles in SLR was begun from a database search, andthe following databases were used for this study: Science Direct, SCOPUS. The reason for selecting these databases was their huge coverage and regular use in conducting 
SLR: e.g., Klang et al. (2014), Nijmeijer et al. (2014), Xiao and Nicholson (2012). "Science Direct covers around 2500 peer-reviewed journals in 24 major scientific disciplines". The selected source type was Journal and data ranges from 2015-2018. The language we choose articles was English. To identify relevant literature, the search string used was deliberately broad in scope and focus according to the exploratory nature of the research. For searching the databases the keywords which were designedconsisted ofthree components, i.e., "consumer purchase regret."

\section{Study Selection}

For the selection of relevant studies, several steps were followed accordingly. Database search was performed in December 2018 and January 2019 and yielded a sumof 472 results. As the first step, we looked and discarded the "duplicate articles" across and within the databases so that articles may not add twice. After doing this in the next step, a comprehensive review of abstracts was performed, using the inclusion criteria for abstract screening. We checked the "titles" and the "abstracts" for the primarily analysis to ensure their relevance to current research questions, and eliminate those which resulted "not relevant." So as a result after this screening out process 100 articles which were possibly important and incorporated these articles in the full-text search. In further step 20 of these articles, in "analyzed databases" were found that full text was not available, meanwhile, for other 80 articles full versionwas entirely analyzed, and it led to eliminating45articles as those were not related to the research questions. Then another 30articles were screened out because they were not written in a consumer behavior context. Finally, the remaining 15 research articles were incorporated for this systematic review. All the steps mentioned above involved in the selection of relevant study are reported below.

During the selection process, only the relevant articles were employed for this study and all the non-relevant articles were excluded, selection criteria are followed. Firstly, the research studies that were focusing only on consumer behavior for different sectors and were not matching our criteria were excluded. Then the articles centered merely on the issues like consumers purchase, and the studies that deal with the effect of dissatisfaction were excluded. Finally, all those studies related to deal with purchase regret, specific methods, technologies, and tools (possess not any constructive evidence to CPR) were excluded.

To choose the final articles for SLR analysis, a further full-text review was conducted. Following the method to deal with full content survey recommended by Wong et al. (2012), each publicationwas checkedby two sets of criteria: topic and quality relevance. Moreover, again we utilize the "inclusion and exclusion" criteria for abstract screening to verify furthereach article is relevant to the research questions. The quality criterion of the current SLR was based on the blend of quality assessment criteria employed byMacpherson and Holt (2007) andWong et al. (2012). According to them, "assessment process includes a review of theory, methodology and methods, analysis, relevance and contribution" and further added by Wonget al. (2012), "an article has to meet the first set ofcriteria and satisfy at least one of the quality criteria to be retained for further analysis".

The utilization of these criteria excluded 30 articles, leaving 15articles for information extraction and combination. The final list of articles recovered appears in Reference.

\section{Discussion}

Literature analysis has shown that many variables regarding CPR attract researchers' attention. Park et al. (2015) discussed after buying cognitive behavior and how the negative 
feelings associated with any purchase can reduce consumer purchase regret in his study and examined the usefulness of cognitive effort to reduce negative emotions, i.e.regret in the context of buyer decision-making. This paper was intended to test the influence of cognitive effort empirically in the search for information on regret after purchase in online and offline shopping situations. They explored how decision making in both online and offline context may differ from each other and how regret may occur after buying. The first step in consumer behavior is information search (Bettman, 1979). In general, the search for information help customers in lowering the risk associated with the purchase.

Moreover,"cognitive efforts are the aggregate use of mental resources and are often described in a similar context in decision-making literature as terms such as mental effort, mental costs, decision-making costs and decision-making efforts" (Johnson, 2008). In particular, this study aims to examine the benefits of cognitive effort in reducing negative emotions such as regret.

Buyer choices are often emotional, and emotions can strongly predict consumers' future behavior (Flavion-Blanco et al. 2011). Among various harmful emotions, regret is known to cause one of the most extreme emotional reactions (Saffrey et al., 2008), so people are reluctant and try to order their regret levels. (Zeelenberg \& Pieters, 2006).

"Regret is a negative feeling when comparing or imagining options for the future and realizing that one could have been in a more favorable situation had they chosen a different option"(Bell, 1982; Zeelenberg, 1999). For instance, Zeelenberg et al. (1998b) argued that regret is a sub-category of disappointment and that a decision-maker will only regret it if the disappointing result is attributed to him/her. Because of a strong relationship between personal responsibility and regret it can further lead (Zeelenberg et al., 1998a; 1998b), "regret often leads to self-blame and may aversively affect one's well-being" (Jokiassair, 2003). Unfortunately, for many consumers, regret is unavoidable and can have lingering negative consequences.

While shopping online, customers have some limitations of not comparing the stuff and material physically, and that is why it is expected that online shopping will generate more regret than offline shopping. Park et al. (2015) described that the level of regret was generally reduced by higher cognitive effort and this effect has been linked to the point of purchase or sort of information. He further suggested that customers should lessen the cognitive effort reduction objective and spend more cognitive effort in certain situations.

Shani et al. (2015) added a neglected, but strong effective variable' missed opportunities' to the literature. According to them, research remains silent as to whether "the effects of missed opportunities can be generalized to opportunities that will be missed in the future" and also what is the impact of these two types of missed opportunities. They discussed four factors which lead to predicting that future failures will have more impact than past failures. The first factor is responsibility. They argue that decision makers generally feel that they have more control over preventing mistakes in the future than past. Since responsibility is a primary determinant of regret (Zeelenberg et al., 2000), failure to prevent a future miss should lead to greater regret compared to a past failure which cannot be overturned. Other three factors that may influence purchase regret were; the ease with which individuals can imagine superior counterfactuals, better forecasting, and recovery from a missed opportunity. Shani et al. (2015) investigated the emotional and behavioral responses of people to missed opportunities. The goal of the study was to examine how individuals choose between regret 
from the past and future options. Even though these relations are impartially unrelated, they can analytically influence decisions so that when customers feel accountable for future failure, they distance themselves by selecting the previous failure option. Individuals prefer to buy from that retailer who previously discounted the product and not from a retailer who will discount it in the future. They also found that people felt more regret for missing future discounts.

Dhir et al. (2016), claim that research on online purchase regret has emerged from last some years. The presence of such regret is resulting in negative usage experience, service switching and discontinuity. A positive experience of an individual with any brand provides the feelings of enjoyment and satisfaction and results in repurchasing the brand and brand loyalty (Chang, 2013; Shi et al., 2010; Gummerus et al., 2012). However, when the experience is negative (due to failure in meeting customer's expectations) can lead to regret and service switching (Kang et al., 2009), lower satisfaction (Buiet al., 2011; Taylor, 1997; Tsiros \& Mittal, 2000) and a negative effect on repurchase intentions (Tsiros \& Mittal, 2000). CPR can be defined as "a negative, cognitively determined emotion that an individual experiences when realizing or imagining that their present situation would have been better had we acted differently" (Zeelenberg, 1999). Previous marketing literature has focused mainly on such regrets, which occurs in offline situations, such as spending more on certain items and then facing regret.Dhir et al. (2016) concluded that adolescents who tend to involve actively in online communities' later regret their participation. Another finding suggested that the participation of SNS brands also contributed to the experience of online regret in Facebook use. There is an important point that either way of involvement (either following content or conversation) requires a significant amount of time every day. Because teenagers spend more time than expected, they tend to regret more.

Rotman et al. (2017) suggested that regret caused a change in psychological and physical warmth and motivated people to improve this change by interacting with objects perceived to be physically or psychologically as opposed to temperature. They also investigated the feelings and emotions associated with action and inaction regret. The theory of emotion describes our subjective emotional experiences as a function of our physical states (Damasio \& Carvalho, 2013). Emotionsare created by a person's perception of the physiological responses associated with them. Experimental support suggested that body expressions and reactions are closely linked to the processing and interpretation of emotional experiences (Damasio, 2000; Niedenthal et al., 2005; 2009). For example, fear is associated with raised heart rate and goosebumps (Oosterwijk et al., 2010). According to, Stepper and Strack (1993) certain physical pose (e.g., standing pose) are linked with specific emotional response (e.g., pride).

Therefore, emotional processes are inherently linked to physiological reactions and contain psychobiological properties such as motor expression, movement, subjective experience and emotional regulation (Fontaine et al., 2007). By these arguments, this study investigated the experiencing some form of regret (action regret) leads to a higher perception of warmth through the experience of self-conscious emotions and creates a desire for cold products (vs. hot).

Rotman et al. (2017) concluded that CPR leads to a change in emotional temperature, which motivates people to improve this change through interaction with consumer objects that are supposed to be physically or psychologically opposite in temperature. Another finding is that 
action regret induces self-conscious emotions that turn warmth (flushness) into a desire for colder drinks. So the conclusion is such individuals who cannot overcome regret may have some mental health problems, as per past research has established a link between regret and both "anxiety and depression" (Roese et al., 2009). In this case, the study (Rotman et al. (2017) investigated that the use of temperature can provide an important regulatory mechanism to address such health problems and improve the overall well-being of people. Hence a simple solution to help firms to reduce the impact of consumer regrets. If someone has action regret, a worker can present a cold drink to minimize their negative emotions.

Wu et al. (2017) investigated the difference between two status of regret, "other- blame regret (O-regret) and self- blame regret (S-regret)," and to examine the actual cause and to limit conditions of the relationship between regret and negative word of mouth (NWOM). 'O and $S$ ' regret relates to a cognitive process in which a person objects to others (or to himself) for the occurrence of a stressful event (Janoff-Bulman, 1979), though 'O and S' regretis not necessarily evenly exclusive in that individuals can blame others while they blame themselves. Customers can feel regret due to different reasons but in this study (Wu et al. (2017) authors proposed that in post-purchase scenarios of regret in which buyers express their own experiences with others, both regrets will have diverseimpacts on anger and sadness leading to a completely different probability of spreading NWOM. In other words, various roles of anger and sadness explain the various consequences of ' $O$ and $S$ ' regret leading to NWOM.

Wu et al. (2017) concluded that customers with O-regret spread more NWOMs than individuals with S-regret, even though they may have the same level of regret. This connection is explained by various negative feelings, such as anger and sadness, which mediate roles in different situations of regret. It can, therefore, be concluded that anger is a dominant emotion when customers having $O$ regret and the effect of regret on NWOM is mediated. Also, the apparent magnitude of the problem itself may not lead to a higher tendency to transmit more NWOM in retail situations. It depends instead on the level of anger experienced by the customer after a purchase. This (Wu et al. (2017) also revealed that feelings of sadness also increase the chance of NWOM when buyers experience $S$ regret.

Gabler et al. (2017) studied that "increasing discount pricing strategy" constantly pits product scarceness against future discounts and push customers to choose among price savings and the possible risk of lost the chance to purchase. In consumer behavior prices play an essential role (Kukar-Kinney et al. 2012). This research advanced the theory of pricing by applying the discount strategies (Gabler \& Reynolds, 2013) to two various settings and product type-site., Scarcity concepts (Jang et al., 2015) and regret (Tsiros, 2009).

According to the findings (Gabler et al. (2017), price consciousness does not affect buying decision regret but directly leads to the decision not to purchase. It also concluded that if there are only a few choices available to buy,then it will increase the regret for both action and inaction. Materialism has a significant positive impact on the purchase and also regret the buy decision in the context of the SID. These results underline how particular features shape aversion to loss and the decision- making process. If the discount for future buying will raise than the CPR for inaction also increase.

Davvetas et al. (2017)examined the moderating role of consumer brand identification (CBI) in response to $C P R$. It indicates that the $C B I$ reduces the adverse effects of $C P R$ and reinforce the 
positive impact of satisfaction on the intention to repurchase/recommend brands. Also, the study (Davvetas et al. (2017) showed that consumer-brand bond helps in reducing cognitive dissonance and emotional regulation. This study also suggested that developing a consumer relationship can protect the brand from superior competitors'. Also, if there is a strong CBI, it can furtherdevelop a link between the customer's identity and the brand's identity. Finally, conclude that strong $\mathrm{CBI}$ can influence and eliminate the negative past experience and CPR. This study (Davvetas et al. (2017) contributed to the theory of regret by suggesting that the occurrence of regret is not identical across brands, but depends heavily on the relationship between customer and brand.

Ha, Youngwook. (2018), investigated the differences that affect consumer preferences when new technologies come into being, between the expected benefit of the existing system and the anticipated advantage of the improved system. The rapid improvement and addition of new technology in products is an important factor which leads to a delay in the decision of the customer to make the purchase or not. With the evolution of IT products., TV or computers are available, it is often apparent that the prices of such products are falling or that customers have the opportunity to purchase products with better options and friendlier prices. In general, "consumers make purchasing decisions based on the expected benefits or values created by using the product" (Davis et al., 1989). However, future expectations would affect consumer behavior if consumers knew that future product would improve significantly from the current one. The theory of regret illustrates the decision - making the process that takes future alternatives into account. According to the regret theory, "the expected emotion arises when the unselected alternative is compared to the value of the selected alternative, which leads to consumer behavior," (Sheeran et al., 1999; Zeelenberg, 1999).

According to the findings (Ha, Youngwook. (2018), the higher the recognition of the advantages of the current system, the lesser the gap in the upgraded system benefit was forecasted. Furthermore, the more the recognition of the advantages of the existing system, the intent to employ the potentialfuture system was also high. The awareness of the benefit of the present system is analyzedto have an indirect effect on the expected regret by comparing it with the benefit of the future system since it has not been statistically proven. The expectedregret was then confirmed to hurtbehavioral intention. This result is in line with previous findings (Baumgartner et al., 2008; Chen et al., 2015; Zeelenberg, 1999).

Mourali et al. (2018) proposed that increased power reduces anticipation of regret and the fear of taking the incorrect decision, so the authors further suggested that power affects the degree of selection by reducing the vulnerability of customers to anticipated regret.

Marketers try to raise traffic in their selling places. However, an increase in store visitors may not result in raising the sales, because customers can postpone the buying decision to avoid the negative emotions that can arise when making difficult tradeoffs between necessary choices. Mourali et al. (2018) investigated how power, one of the most pervasive social world forces (Keltner et al., 2003), influences the tendency of customers to postpone the decision. Customers experience natural feelings of power and powerlessness and these feelings can come from many sources, including the perception of customers' opinion of their socioeconomic status (Henry, 2005), and bargaining position (Dwyer, 1984). The key findings (Mourali et al. (2018)are that increased power encourages action, while powerlessness led to inaction and evasion. Another finding indicates that while poweris generally related with less delay, but it can lead consumers to make no choices in some situations. Due to this method, 
there are psychological factors that make regret significant or reduced, such as reversibility of results and locus of regrets (postponing vs. choose now) could change the tendency of consumers to postpone their decision. Likewisein situations where customers' having confidence in choices, they made can drive them away from regret. Another finding suggested that if individuals associate inaction with more regret than action, the powerless should be even more likely to act than the powerful. The customers' state of power influenced the CPR. However, other factors then power can also affect the anticipation and probability of a postponement of choice. For instance, "people are less likely to expect regret when the outcome of a decision can easily be reversed (Zeelenberg et al., 1996)."

Park et al. (2018)stated that in the last 25 years, e-commerce has seen tremendous growth, and in 2015 e-commerce expenditure in the United States was close to $\$ 350$ billion (Smith \& Anderson, 2016), $f 52.25$ billion in the UK (Moth, 2015). Although e-commerce progress is growing rapidly a broad understanding of customer behavior is lagging in online shopping environments. Park et al. (2018) tried to investigate the regret of consumers regarding cognitive efforts and justification in online shopping. In addition to justification, cognitive efforts are equally valuable to customers. Cognitive effort results in increased decision confidence and accuracy (Bettman et al., 1998). The key finding of the (Park et al. (2018) was that more cognitive research efforts could help decision-makers to mitigate their old regrets even if the effort does not pay off in terms of accuracy. It may mean that customers have to make more cognitive efforts to avoid future regrets. Another finding is that if customer schmooze to deviate from their early decision and make a spontaneous purchase, and if they have already made a cognitive effort to make the other choice than it will be better not to think why they needed the initial product, to feel less regret. When customers have time to process product information, they tend to believe that they have made sufficient cognitive effort in the decision and therefore suffer a lesser amount of regret.

Liao et al. (2017) adopts the theory of expectation confirmation (ECT) and regret to examine the effects of external reference points on repurchase behaviors and to examine how the search effort of customers persuades satisfaction and regret. They found that alternative attractiveness indirectly affects satisfaction and the intention to repurchase by regret. Another finding is that CPR has an effect on the intention to repurchase and mediates the impact of alternative attractiveness on satisfaction and repurchases intentions. It also suggested that high attractiveness of alternatives can lead to CPR, but search effort not only contributes to post purchase satisfaction but also reduces CPR. We concluded that level of loyalty could generate more repurchasing through inducing positive emotions (e.g.,satisfaction) but it may not be able to reduce the impact of negative emotions (e.g., regret) on repurchasing.

Davvetas et al. (2018) further argued on the basis of regret theory that the affordability of selected and forgotten global/local brands affects the response of customers to regrettable purchases and that the direction and scope of this impact depends on the category of products and the global identity of consumers. The findings showed that according to the consumer regret theory, the features of selected and forgiven brands could regulate the degree of consumer regrets after critical comparisons with superior competitors. Davvetas et al. (2018) also identified that brand globality and locality could influence consumer emotions and help them to deal better with the emotional discomfort caused by comparisons with 
unchosen products. Therefore, brand globalization and locality act as emotional regulators by acting as catalysts of regret or as immunizers of regret when global/local brand choices go wrong.

Seung-Hee Lee \& Jane E. Workman (2018) demonstrated that the emotional state of the customer after purchasing / non-purchasing is affected by regret that can further lead to either dissatisfaction, negative word of mouth or low repurchase intention. CPR is defined as "the propensity of consumers to experience regret following a decision to purchase or not to purchase a product or service" (Delacroix \& Jourdan, 2007). Compulsive buying is "chronic repetitive purchasing that becomes a primary response to negative events or feelings" (O’Guinn \& Faber, 1989).

According to Delacroix and Jourdan (2007), customers who respond quickly(earlier adopters) inbuying decisions are more likely to regret the purchase, but customers who delay purchase decisions (e.g., later adopters) are more likely to regret not purchasing. They also established that women were more likely to regret than men. Since compulsive shoppers shop more oftenthat's why they have more chances of havingpost purchase regret and also depends of level of product involvement, they also found that customers may not regret buying when they can return the item as returns are indicative of CPR.

Kuang et al. (2018) investigated the effect of uncertainty about valuation and expected regrets on customer buying behavior, business prices and cost strategy. They considered a company that sells two substitutes over two periods, one product for one period, in a sales season. The company declared all price ranges at the start of the sales period (price commitment) or the beginning of each period (dynamic pricing) every price. Also, a consumer may regret buying if he or she decided to buy in the first period or postponed.

Kuang et al. (2018) found that the prices of the two alternative products are positively correlated. However, the price of product 1 is lower than product 2, despite the higher average value of product 1 .. The results also showed that the effects of each type of expected CPR on the prices of the company could be opposite and depend on the uncertainty conditions. The optimum price for the second-period increased in regret of purchase and decreased in regret of waiting when the uncertainty is moderate. If there is greater uncertainty and customers expect much more aversion to buying regret, the effects can change the other way around. Although purchase regret mostly raises the price of the second period, it's hamfatter company's overall demand and profit. The reason is that buying regrets lead to strategic waiting and therefore leads customers to share some of the risks to the company due to uncertainty. So these findings also justify the importance of return policy in daily life, which diminish the adverse effects of CPR.

Finally, due to the strategic behavior of consumers in determining the possible price for the second period the level of uncertainty and expected regrets affect the value of the price commitment.

Chen et al. (2015) introduced a conceptual model that shows that when customers psychologically generate supposed scenarios where they anticipate the regret, they may feel after the use of counterfeit products (For example, other buyers find their product to be a fake rather than an iconic luxury brand), than customers are more likely to choose a nonconspicuous option than a conspicuous one. More expressly, considering that obvious typical counterfeited items are linked to the higher possibility of regret, this research suggested that 
customers are more inclined to buy a counterfeit luxury product without a logo than a counterfeit luxury product with a logo. The aim of this study was, therefore, to investigate the reduced desire of consumers for "conspicuous prototypical counterfeit luxury products" by examining how anticipated regret influences their preference for the purchase of such products and the finding of this study was that customers are less likely to buy anobvious counterfeit product if they anticipate their regret. 
INTERNATIONAL JOURNAL OF ACADEMIC RESEARCH IN BUSINESS AND SOCIAL SCIENCES

Vol. 9, No. 9, September, 2019, E-ISSN: 2222-6990 @ 2019 HRMARS

\begin{tabular}{|c|c|c|c|c|c|}
\hline \multicolumn{6}{|c|}{ Table :1 } \\
\hline Variables & $\begin{array}{l}\text { Research } \\
\text { Methodology }\end{array}$ & $\begin{array}{l}\text { Data } \\
\text { Collection }\end{array}$ & Sampling Test & Sample Size & Reference \\
\hline Regret, Cognitive effort, Online and offline shopping & $\begin{array}{l}\text { Experimental } \\
\text { Study Survey }\end{array}$ & Questionnaire & $\begin{array}{l}\text { Connivance } \\
\text { sampling }\end{array}$ & $\begin{array}{l}\text { Study 1: } 147 \\
\text { Study 2: } 129\end{array}$ & $\begin{array}{l}\text { Park et al. } \\
\text { (2015) }\end{array}$ \\
\hline $\begin{array}{c}\text { Future regret, Past regret, Counterfactuals, Missed } \\
\text { opportunities, Responsibility, Promotions }\end{array}$ & $\begin{array}{l}\text { Experimental } \\
\text { Study Survey }\end{array}$ & Questionnaire & $\begin{array}{l}\text { Purposive } \\
\text { sampling }\end{array}$ & $\begin{array}{l}\text { Study 1: } 30 \\
\text { Study 2: } 60 \\
\text { Study 3: } 111 \\
\text { Study 4: } 120 \\
\end{array}$ & $\begin{array}{l}\text { Shani et al. } \\
\qquad(2015)\end{array}$ \\
\hline $\begin{array}{l}\text { Adolescents, Cross-sectional, Facebook, Online regret } \\
\text { experience, } \\
\text { SNS brand participation, Problematic use }\end{array}$ & Survey & Questionnaire & $\begin{array}{l}\text { Purposive } \\
\text { sampling }\end{array}$ & 804 & $\begin{array}{l}\text { Dhir et al. } \\
\text { (2016) }\end{array}$ \\
\hline $\begin{array}{l}\text { Experiencing action regret, Change in psychological and } \\
\text { physical warmth }\end{array}$ & $\begin{array}{l}\text { Experimental } \\
\text { Study Survey }\end{array}$ & Questionnaire & $\begin{array}{l}\text { Purposive } \\
\text { sampling }\end{array}$ & $\begin{array}{l}\text { Study 1: } 157 \\
\text { Study 2: } 109 \\
\text { Study 3: } 121 \\
\text { Study 4: } 119\end{array}$ & $\begin{array}{l}\text { Rotman et al. } \\
\qquad(2017)\end{array}$ \\
\hline $\begin{array}{c}\text { Negative word of mouth, Anger, Blame attribution, Sadness, } \\
\text { Other-blame regret, Self-blame regret }\end{array}$ & Survey & Questionnaire & $\begin{array}{l}\text { Purposive } \\
\text { sampling }\end{array}$ & 111 & $\begin{array}{l}\text { Wu et al. } \\
(2017)\end{array}$ \\
\hline $\begin{array}{c}\text { Regret, Scarcity, Discount, Omission bias, Expected utility, } \\
\text { Retail }\end{array}$ & Online Survey & Questionnaire & $\begin{array}{l}\text { Convenience } \\
\text { sampling }\end{array}$ & $\begin{array}{l}\text { Study 1: } 339 \\
\text { Study2: } 421\end{array}$ & $\begin{array}{c}\text { Gabler et al. } \\
\text { (2017) }\end{array}$ \\
\hline $\begin{array}{c}\text { Consumer-brand identification, Regret, Satisfaction, } \\
\text { Consumer-brand relationships }\end{array}$ & Survey & $\begin{array}{c}\text { Personal } \\
\text { interviews } \\
\text { Questionnaire } \\
\end{array}$ & Quota sampling & 350 & $\begin{array}{l}\text { Davvetas et } \\
\text { al. (2017) }\end{array}$ \\
\hline Behavioural intention, Anticipated regret, Expectations gap & Online Survey & Questionnaire & $\begin{array}{l}\text { Convenience } \\
\text { sampling }\end{array}$ & 805 & $\begin{array}{l}\text { Ha et al. } \\
(2018)\end{array}$ \\
\hline
\end{tabular}


INTERNATIONAL JOURNAL OF ACADEMIC RESEARCH IN BUSINESS AND SOCIAL SCIENCES

Vol. 9, No. 9, September, 2019, E-ISSN: 2222 -6990 @ 2019 HRMARS

\begin{tabular}{|c|c|c|c|c|c|}
\hline $\begin{array}{c}\text { Power, Choice deferral, Decision confidence, Anticipated } \\
\text { regret, Decision difficulty }\end{array}$ & $\begin{array}{l}\text { Experimental } \\
\text { Study Survey }\end{array}$ & Questionnaire & $\begin{array}{l}\text { Convenience } \\
\text { sampling }\end{array}$ & $\begin{array}{l}\text { Study 1a: } 180 \\
\text { Study 1b: } 216 \\
\text { Study 2: } 256 \\
\text { Study 3: } 126 \\
\text { Study 4: } 124 \\
\text { Study 5: } 108 \\
\text { Study 6: } 31\end{array}$ & $\begin{array}{l}\text { Mourali et al. } \\
\text { (2018) }\end{array}$ \\
\hline Cognitive effort, justification, regret, online shopping & $\begin{array}{l}\text { Experimental } \\
\text { Study Survey }\end{array}$ & Questionnaire & $\begin{array}{l}\text { Convenience } \\
\text { sampling }\end{array}$ & $\begin{array}{l}\text { Study 1: } 112 \\
\text { Study 2: } 178\end{array}$ & $\begin{array}{l}\text { Park et al. } \\
(2018)\end{array}$ \\
\hline $\begin{array}{c}\text { Expectancy confirmation theory, Regret, Alternative } \\
\text { attractiveness, Information search, Repurchase intention, } \\
\text { Satisfaction }\end{array}$ & $\begin{array}{l}\text { Web based } \\
\text { survey }\end{array}$ & Questionnaire & $\begin{array}{l}\text { Purposive } \\
\text { sampling }\end{array}$ & 268 & $\begin{array}{l}\text { Liao et al. } \\
(2017)\end{array}$ \\
\hline $\begin{array}{c}\text { Global brands, local brands, regret, postpurchase behavior, } \\
\text { justifiability, global identity }\end{array}$ & $\begin{array}{l}\text { Web based } \\
\text { survey }\end{array}$ & Questionnaire & $\begin{array}{l}\text { Quota Purposive } \\
\text { sampling }\end{array}$ & $\begin{array}{l}\text { Study 1: } 98 \\
\text { Study 2: } 122 \\
\text { Study 3: } 113 \\
\text { Study 4: } 203\end{array}$ & $\begin{array}{l}\text { Davvetas et } \\
\text { al. (2018) }\end{array}$ \\
\hline $\begin{array}{l}\text { Tendency to regret, compulsive buying, fashion, time-of- } \\
\text { adoption groups, gender }\end{array}$ & Survey & Questionnaire & $\begin{array}{l}\text { Purposive } \\
\text { sampling }\end{array}$ & 195 & $\begin{array}{l}\text { Lee et al. } \\
(2018)\end{array}$ \\
\hline $\begin{array}{c}\text { Substitutable products; anticipated regret; second period } \\
\text { valuation } \\
\text { uncertainty; pricing strategy }\end{array}$ & $\begin{array}{l}\text { Qualitative } \\
\text { Study }\end{array}$ & & & & $\begin{array}{l}\text { Kuang et al. } \\
\qquad(2018)\end{array}$ \\
\hline $\begin{array}{l}\text { Anticipating regret; Non-conspicuous counterfeits'; } \\
\text { Perceived risk }\end{array}$ & $\begin{array}{l}\text { Experimental } \\
\text { Study Survey }\end{array}$ & Questionnaire & $\begin{array}{l}\text { Purposive } \\
\text { sampling }\end{array}$ & $\begin{array}{l}\text { Study 1: } 69 \\
\text { Study 2: } 70 \\
\text { Study 3: } 71 \\
\text { Study 4: } 128\end{array}$ & $\begin{array}{l}\text { Chen et al. } \\
\text { (2015) }\end{array}$ \\
\hline
\end{tabular}




\section{Conclusion}

As the famous philosopher, Amiel shared, "Accept life and must accept regret" (HenriFrerder Ric Amiel, 1821-1881). This quotation reflects the widespread and unavoidable feeling of regret. It also raises doubts as to whether "we can achieve the idealization about which Edith Piaf famously sang: living a life without regrets." Svenson's theory of decision-making differentiation and consolidation recommends that "two common objectives of all decisions are to limit cognitive dissonance and the potential for regret achieved through the cognitive process of differentiating the choice from one another" (Svenson, 1992).

If one of the main objectives of decision-making is to lessen regret, it is essential to know its conception, how to avoid or reduce this and how to measure it. All individuals have to take different sort of decisions in different contexts in everyday lives, and they can cause both CPR of action or inaction. Regret has drawn the attention of researchers in various fields of research, including business and economics (Lin et al., 2006).

Following a five-step approach to the systematic review of the literature, this paper analyzed and synthesized the findings of 15 peer-reviewed papers published between 2015 and 2018, primarily from marketing and consumer behavior literature. We focused our literature review on the reasons for CPR. We have summed up our findings in three processes of order fulfillment that influence and antecedents of CPR and its results. Using a systematic review, we intended to (i) identify the reasons of occurring purchase regret, and its antecedents (ii) elaborate the consequences of CPR (iii) and how it can be overcome.

According to Park et al. (2015), the level of regret was generally reduced by higher cognitive effort, andthis effect interacts with the purchase point or relevant information. However, customer scan spend more cognitive effort in certain situations for avoiding CPR. However, on another side, Shani et al. (2015) elaborated that individuals desire to be fully learned about their past and future decisions, especially when this information can develop further decision- making. However, customers respond more negatively to future (rather than past) opportunities information that they may miss because knowing that if these opportunities may miss, it can raise the regret.

CPR in online purchases is now getting higher in teenagers because they spend more time on the internet than others and such adolescents who are currently overusing internet (e.g., Facebook) are tend to have greater regret. Young users with different accessibility of technology did not vary in their online experience of regret, but thoseextreme Facebook users and also aggressively involved in brand communities can have more regret (Dhir et al., 2016).

According to Rotman et al. (2017), individuals who cannot overcome regret may have some mental health problems; past research findings have established a relationship between regret and both anxiety and depression (Roese et al., 2009). And Rotman established through experimental research the use of temperature could provide a vital regulatory framework for addressing such types of health and regret issues. Hence a simple solution to help firms to reduce the impact of consumer regrets. If 
someone has action regret, a customer service worker can offer a cold drink to minimize the level of regret and anger.

It can be concluded that anger and sadness are the dominant emotions when customers' experience ' $O$ ' and ' $S$ ' regret respectively, and they also mediate the effect of regret on NWOM. Moreover, the feelings of sadness also increase the probability of NWOM when buyers experience S-regret (Wu et al., 2017).

As per the findings of Gabler et al. (2017) discussing antecedents of CPR; price consciousness is not a reason for regret but can be a cause of not to purchase. He also found that if the number of substitute availability is low, thenbothactionand inaction regret will be high. Materialism also has a positive impact on the buying and the regret associated with this decisional, et al. (2018) concluded that the comparison of choices forms regret and it also mighthurtthe behavioral intentions of customers.

However, on the other hand, Davvetas et al. (2017) argued that experience of regret is not the same across all brands, but depends heavily on the relationship between the customer and the brand.

Another finding from the theory of power approach/inhibition is that increased power encourages action, while powerlessness led to inaction and avoidance (Mourali et al., 2018).It also found that the tendency of buyers to postpone their choice could change psychological factors that cause an increase or reduce regret, such as reversibility of results and location of regrets (postponing vs. selecting now). An additional contribution to CPR literature is that more cognitive research efforts can help decision-makers to mitigate their experienced regrets. Thus, to avoid possible future regret, customers will make more cognitive efforts (Park et al., 2018).

Liao et al. (2017) also suggested that CPR can affect the intention to repurchase, butthe level of satisfaction candidate the effects on repurchase intentions. Alternative attractiveness has an importantdirect positive effect on CPR. The search effort hurts CPR, so it can increase the level of satisfaction and can decrease CPR.

According to the consumer regret theory, the characteristics of selected and forgiven brands canbe regulated the extent of consumer regrets after adverse comparisons with better competitors. So, in that case, Davvetas et al. (2018) identified that brand globality and locality could influence consumer emotions, therefore, brand globalization and locality act as emotional regulators by acting as a precursor of regret or as immunizers of regret when global or local brand decisions went wrong.

Lee et al. (2018) found that both types of buyers (early and late adopters) are more likely to have CPR, either regret of buying or regret of not buying. Also found that women were more inclined than men to regret. Moreover, also agree to other researches that since compulsive shoppers buy more often so, it is logical to expect that they will have more chances to post purchase regret, butlf customers have the option to return the item, they may not regret because such options are indicative of purchase regrets. Kuang et al. (2018) also agreed that the existence of return policy reduces the negative effects of purchase regret. Moreover,finally, the literature on CPR contributed about counterfeiting products, it suggested that while buying 
counterfeiting products customers anticipate more regret if other people find that this productis fake that is why counterfeited products may increase purchase regret,and they also come with no return policy (Chen et al., 2015).

\section{Contribution to the Research}

This SLRenrichedthe existing body of knowledge and advanced understanding ofCPR. First, this study uses a comprehensive and rigorous systematic analysis of the literature review to describe the concept of purchase regret and evolution of the concept over the period. Second, dominant theoretical perspectives are identified used by literature to see through thepresent findings on the topic. Third, this study consolidates issues associated with CPR and classifies them. These classifications provide a list of variables that have received significant scholarly attention. Fourth, this study provides major methodical approaches used by researches to examine CPR.

\section{Limitations of the Research}

There are some limitations of the study that should be considered while generalizing the results of the study. There is one of the most common limitations that selected articles were constrained to satisfied keywords and selection criteria. Future researches can gain more insight by considering additional knowledge in books, magazines and practitioner articles. This study solely focuses on academic journals; future studies can enrich the concept by considering articles and published material beyond academic journals. Furthermore, future researchers are recommended to carry out a quantitative meta-analysis and confirm the relationships and effects among these factors. 


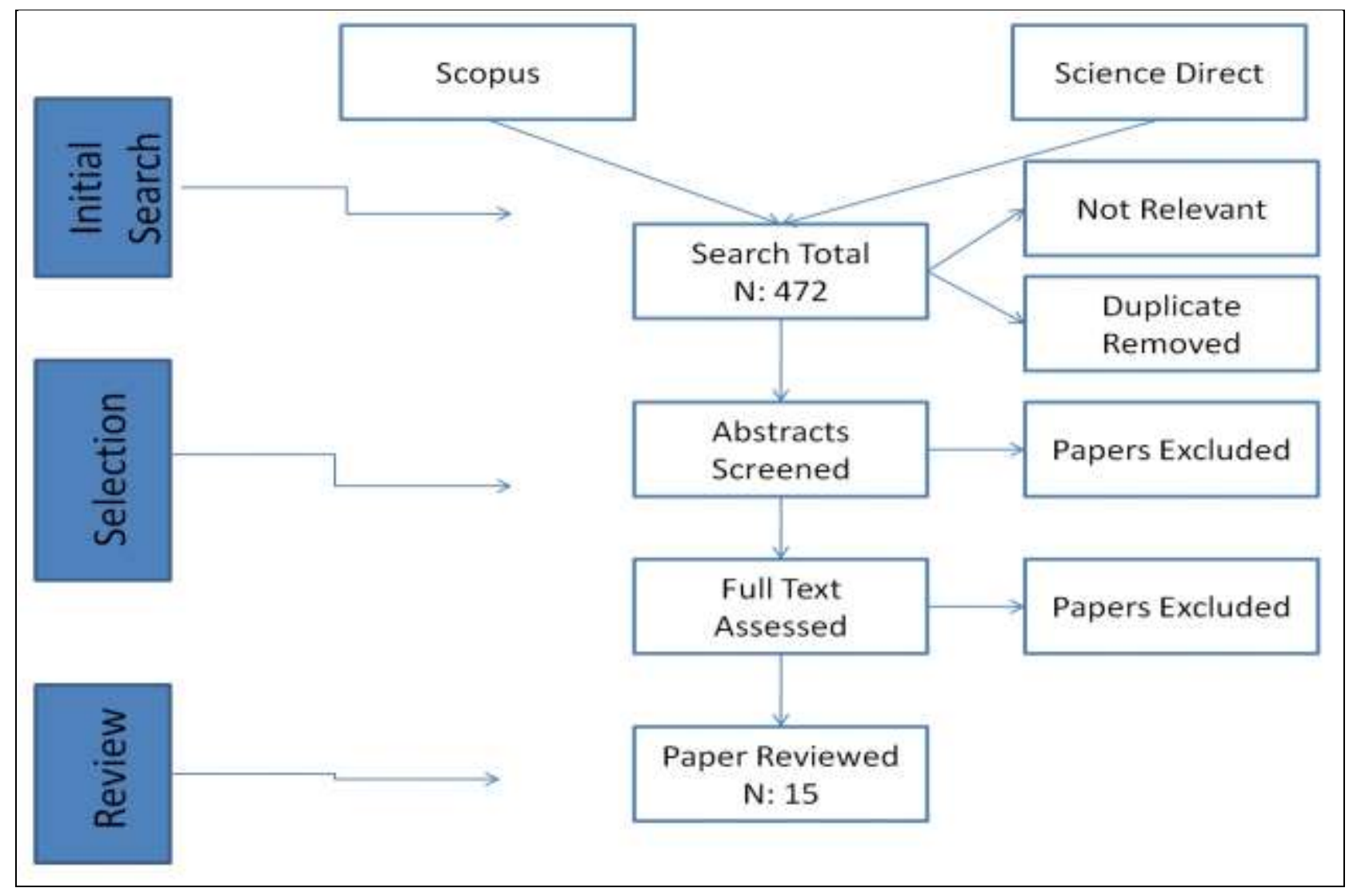

Figure 1: Data Selection

\section{References}

1. Baumgartner, H., Pieters, R. and Bagozzi, R.vP. (2008), "Future-oriented emotions: conceptualization and behavioral effects," European Journal of Social Psychology, Vol. 38 No. 4, pp. 685-696.

2. Bettman, J. R. (1979). An information processing theory of consumer choice. Reading, MA: Addison-Wesley.

3. Bettman, J. R., Johnson, E. J., Luce, M. F., \& Payne, J. W. (1993). Correlation, conflict, and choice. Journal of Experimental Psychology: Learning, Memory, and Cognition, 19, 931-951. doi: 10.1037//0278 7393.19.4.931

4. Bettman, J. R., Luce, M. F., \& Payne, J. W. (1998). Constructive consumer choice processes. Journal of Consumer Research, 25, 187-217. doi: 10.1086/209535

5. Bui, M., Krishen, A. S., \& Bates, K. (2011). Modeling regret effects on consumer postpurchase decisions. European Journal of Marketing, 45(7/8), 1069e1090.

6. Chang, C.-C. (2013). Examining users' intention to continue using social network games: a flow experience perspective. Telematics and Informatics, 30(4), 311e321.

7. Chen, J., Teng, L., Liu, S. and Zhu, H. (2015), "Anticipating regret and consumers' preferences for counterfeit luxury products," Journal of Business Research, Vol. 68 No. 3, pp. 507-515. 
8. Cooper, M. L., Frone, M. R., Russell, M., \& Mudar, P. (1995). Drinking to Regulate Positive and Negative Emotions - a Motivational Model of AlcoholUse. Journal of Personality and Social Psychology, 69, 9901005.

9. Damasio, A. R. (2000). The feeling of what happens: Body and emotion in the making of consciousness: Houghton Mifflin Harcourt.

10. Damasio, A., \& Carvalho, G. B. (2013). OPINION The nature of feelings: evolutionary and neurobiological origins. Nature Reviews Neuroscience, 14, 143-152.

11. Davis, F. D., B agozzi, R. P. and Warshaw, P. R. (1989), "User acceptance of computer technology: a comparison of two theoretical models," Management Science, Vol. 35 No. 8, pp. 982-1003.

12. Davvetas, V., \& Diamantopoulos, A. (2017). "Regretting your brand-self?" The moderating role of consumer-brand identification on consumer responses to purchase regret.Journal of Business Research,80, 218-227. doi: 10.1016/j.jbusres.2017.04.008.

13. Davvetas, V., \& Diamantopoulos, A. (2018). "Should have I Bought the other One?" Experiencing Regret in Global versus Local Brand Purchase Decisions. Journal of International Marketing, 26(2), 1-21. doi: 10.1509/jim.17.0040.

14. Delacroix, E., \& Jourdan, P. (2007). Consumer tendency to regret: Validation of a measurement scale. Recherche et Applications en Marketing (English edition), 22(1), 25-44.

15. Denyer, D. and Tranfield, D. (2009). Producing a systematic review. In Buchanan, D. and Bryman, A. (Eds), The Sage Handbook of Organizational Research Methods. Thousand Oaks, CA: Sage Publications, pp. 671-689.

16. Dhar, R. (1997). Consumer preference for a no choice option. Journal of Consumer Research, 24(September), 215-231.

17. Dhir, Amandeep, Kaur, Puneet, Chen, Sufen, \& Lonka, Kirsti. (2016). Understanding online regret experience in Facebook use-Effects of brand participation, accessibility \& problematic use. Computers in Human Behavior, 59, 420-430.

18. Dwyer, F. R. (1984). Are two better than one? Bargaining behavior and outcomes in an asymmetrical power relationship. Journal of Consumer Research, 11(September), 680-683.

19. Flavi6n-Blanco, C., Gurrea-Sarasa, R., \& Orъs-Sanclemente, C. (2011). Analyzing the emotional outcomes of the online search behavior with search engines. Computers in Human Behavior, 27, 540-551. http://dx.doi.org/10.1016/j.chb. 2010.10.002.

20. Fontaine, J. R. J., Scherer, K. R., Roesch, E. B., \& Ellsworth, P. C. (2007). The world of emotions is not two dimensional. Psychological Science, 18, 10501057.

21. Gabler, C. B., \& Reynolds, K. E. (2013). Buy now or buy later: The effects of scarcity and discount on purchase decisions - Journal of Marketing Theory \& Practice, 21(4), 441-455. 
22. Gabler, Colin, B., Landers, V., Myles, \& Reynolds, Kristy, E. (2017). Purchase decision regret: Negative consequences of the Steadily Increasing Discount strategy. Journal of Business Research, 76, 201-208.

23. Garbarino, E. C., \& Edell, J. A. (1997). Cognitive effort, affect, and choice. Journal of Consumer Research, 24, 147-158.

http://dx.doi.org/10.1086/209500.

24. Grant, R., Clarke, R. J., \& Kyriazis, E. (2007). A review of factors affecting online consumer search behaviour from an information value perspective. Journal of Marketing Management, 23, 519-533. http://dx.doi.org/10.1362/026725707X212801.

25. Gummerus, J., Liljander, V., Weman, E., \& Pihlstr€om. (2012). Customer engagement in a Facebook brand community. Management Research Review, 35(9), 857e877.

26. Ha, Youngwook. (2018). Expectations gap, anticipated regret, and behavior intention in the context of rapid technology evolvement. Industrial Management \& Data Systems, 118(3), 606-617.

27. Henry, P. C. (2005). Social class, market situation, and consumers' metaphors of (dis)empowerment. Journal of Consumer Research, 31(March), 766-778.

28. Chin-Ho, Lawrence, J., Sanna, Edward. (2006). Judgments over time: The interplay of thoughts, feelings, and behaviors: Oxford University Press.

29. Julsin, P., Montgomery, H. (eds) Judgement and Decision Making: NeoBrunswikian and Process Tracking Approaches. New Jersey: LEA Publishers, 1999: 175-198.

30. Jang, W. E., Ko, Y. J., Morris, J. D., \& Chang, Y. (2015). Scarcity message effects on consumption behavior: Limited edition product considerations. Psychology and Marketing, 32(10), 989-1001.

31. Janoff-Bulman, R. (1979), "Characterological versus behavioral self-blame: inquiries into depression and rape," Journal of Personality and Social Psychology, Vol. 37 No. 10, pp. 1798-1809.

32. Johnson, E. J. (2008). Man, my brain is tired: Linking depletion and cognitive effort in choice. Journal of Consumer Psychology, 18(1), 14-16. http://dx.doi.org/10.1016/j.jcps.2007.10.003.

33. Jokiassair, M. (2003). Regret appraisals, age, and subjective well-being. Journal of Research in Personality, 37, 487-503. http://dx.doi.org/10.1016/s00926566(03)00033-3.

34. Keltner, D., Gruenfeld, D. H., \& Anderson, C. (2003). Power, approach, and inhibition. Psychological Review, 110(April), 265-284.

35. Kim, M., \& Lennon, S. J. (2008). The effects of visual and verbal information on attitudes and purchase intentions in Internet shopping. Psychology \& Marketing, 25(2), 146-178. http://dx.doi.org/10.1002/mar.20204.

36. Klang, D., Walln"ofer, M. and Hacklin, F. (2014). The business model paradox: a systematic review and exploration of antecedents. International Journal of Management Reviews, 16, pp. 454-478.

37. Kuang, Y., \& Ng, C. (2018). Pricing substitutable products under consumer regrets. International Journal Of Production Economics, 203, 286-300. doi: 10.1016/j.ijpe.2018.07.006. 
38. Kukar-Kinney, M., Ridgway, N., \& Monroe, K. (2012). The Role of Price in the Behavior and Purchase Decisions of Compulsive Buyers. Journal of Retailing, 88(1), 63-71. doi: 10.1016/j.jretai.2011.02.004.

39. Landman, J. (1993). Regret: the persistence of the possible. New York: Oxford University Press.

40. Leeflang, P. S. H., \& Wittink, D. R. (2000). Models for marketing decisions: Postscriptum. International Journal of Research in Marketing, 17, 237-253.

41. Liao, C., Lin, H., Luo, M., \& Chea, S. (2017). Factors influencing online shoppers' repurchase intentions: The roles of satisfaction and regret. Information \& Management, 54(5), 651-668. doi: 10.1016/j.im.2016.12.005.

42. Lin, C., Huang, W., \& Zeelenberg, M. (2006). Multiple reference points in investor regret.Journal Of Economic Psychology,27(6), 781-792. doi: 10.1016/j.joep.2006.03.004.

43. Macpherson, A., and Holt, R. (2007). Knowledge, learning and small firm growth: a systematic review of the evidence. Research Policy, 36, pp. 172-192.

44. Mano, H. and Oliver, R. L. (1993), "Assessing the dimensionality and structure of the consumption experience: evaluation, feeling and satisfaction," Journal of Consumer Research, Vol. 20 No. 3, pp. 451-466.

45. Moth, D. (2015, January 26). UK online retail sales to reach $£ 52.25 \mathrm{bn}$ in 2015 : report. Retrieved from https://econsultancy.com/blog/66007-uk-onlineretailsales-to-reach-52-25bn-in-2015-report/

46. Mourali, Mehdi, Yang, Zhiyong, Pons, Frank, \& Hassay, Derek. (2018). Consumer power and choice deferral: The role of anticipated regret. International Journal of Research in Marketing, 35(1), 81-99.

47. Niedenthal, P. M., Barsalou, L. W., Winkielman, P., Krauth-Gruber, S., \& Ric, F. (2005). Embodiment in attitudes, social perception, and emotion. Personality and Social Psychology Review, 9, 184-211.

48. Niedenthal, P. M., Mondillon, L., Winkielman, P., \& Vermeulen, N. (2009). Embodiment of Emotion Concepts. Journal of Personality and Social Psychology, 96, 1120-1136.

49. Nijmeijer, Karlijn, J., Fabbricotti, Isabelle, N., \& Huijsman, Robbert. (2014). Making franchising work: A framework based on a systematic review. International Journal of Management Reviews, 16(1), 62-83.

50. O'Guinn, T., \& Faber, R. (1989). Compulsive buying: A phenomenological exploration. Journal of Consumer Research, 16, 147-157.

51. Oosterwijk, S., Topper, M., Rotteveel, M., \& Fischer, A. H. (2010). When the mind forms fear: Embodied fear knowledge potentiates bodily reactions to fearful stimuli. Social Psychology and Personality Science, 1, 65-72.

52. Park, J., \& Hill, W. (2018). Exploring the role of justification and cognitive effort exertion on post-purchase regret in online shopping. Computers In Human Behavior, 83, 235-242. doi: 10.1016/j.chb.2018.01.036.

53. Research Center website: http://www.pewinternet.org/2016/12/19/onlineshopping-and e-commerce/

54. Roese, N. J., Epstude, K., Fessel, F., Morrison, M., Smallman, R., Summerville, A., Galinsky, A. D., \& Segerstrom, S. (2009). Repetitive Regret, Depression, and 
Anxiety: Findings from a Nationally Representative Survey. Journal of Social and Clinical Psychology, 28, 671-688.

55. Rotman, J., Lee, S., \& Perkins, A. (2017). The warmth of our regrets: Managing regret through physiological regulation and consumption. Journal of Consumer Psychology, 27(2), 160-170. doi: 10.1016/j.jcps.2016.08.008.

56. Saffrey, C., Summerville, A., \& Roese, N. J. (2008). Praise for regret: People value regret above other negative emotions. Motivation and Emotion, 32, 4654. http://dx.doi.org/10.1007/s11031-008-9082-4.

57. Lee, Seung-Hee, \& Workman, J. E. (2018). Consumer tendency to regret, compulsive buying, gender, and fashion time-of-adoption groups. International Journal of Fashion Design, Technology and Education, 11(3), 265276.

58. Shani, Y., \& Zeelenberg, M. (2007). When and why do we want to know? How experienced regret promotes post-decision information search. Journal of Behavioral Decision Making, 20, 207-222.

59. Shani, Y., Danziger, S., \& Zeelenberg, M. (2015). Choosing between options associated with past and future regret. Organizational Behavior And Human Decision Processes, 126, 107-114. doi: 10.1016/j.obhdp.2014.11.001.

60. Sheeran, P. and Orbell, S. (1999), "Augmenting the theory of planned behavior: roles for anticipated regret and descriptive norms," Journal of Applied Social Psychology, Vol. 29 No. 10, pp. 2107-2142.

61. Shi, N., Lee, M. K. O., Cheung, C. M. K., \& Chen, H. (2010). The continuance of online social networks: how to keep people using Facebook?. In Proceedings of 43rd Hawaii international conference on system sciences, Hawai, USA (pp. 1e10).

62. Smith, A., \& Anderson, M. (2016). Online shopping and e-Commerce. Retrieved from Pew

63. Stepper, S., \& Strack, F. (1993). Proprioceptive Determinants of Emotional and Nonemotional Feelings. Journal of Personality and Social Psychology, 64, 211220.

64. Svenson, O. (1992). Differentiation and consolidation theory of human decision making: A frame of reference for the study of pre- and post-decision processes. Acta Psychologica,80(1-3), 143-168. doi: 10.1016/00016918(92)90044-e.

65. Tsiros, M. (2009). Releasing the regret lock: Consumer response to new alternatives after a sale. Journal of Consumer Research, 35(6), 1039-1059

66. Tsiros, M., \& Mittal, V. (2000). Regret: a model of Its antecedents and consequences in consumer decision making. Journal of Consumer Research, 26(4), 401e417.

67. Tucker, J. (2009, August 10). Social networking has hidden dangers for teens. San Franscisco Chronicle. Retrieved from http://www.sfgate.com/news/article/ Social-networking-has hidden-dangersfor-teens-3289805.php.

68. Wong, C., Skipworth, H., Godsell, J. and Achimugu, N. (2012). Towards a theory of supply chain alignment enablers: a systematic literature review. Supply Chain Management: An International Journal, 17, pp. 419437. 
69. Wu, R., \& Wang, C. (2017). The asymmetric impact of other-blame regret versus self-blame regret on negative word of mouth. European Journal of Marketing, 51(11/12), 1799-1816. doi: 10.1108/ejm-06-2015-0322.

70. Xiao, S., \& Nicholson, M. (2012). A Multidisciplinary Cognitive Behavioural Framework of Impulse Buying: A Systematic Review of the Literature. International Journal Of Management Reviews, 15(3), 333-356. doi: 10.1111/j.1468-2370.2012.00345.x.

71. Young, K. S. (2001). Tangled in the web: Understanding cybersex from fantasy to addiction. Bloomington, IN: Authorhouse.

72. Zeelenberg, M. (1999). Anticipated regret, expected feedback and behavioral decision making. Journal of Behavioral Decision Making, 12(2), 93-106

73. Zeelenberg, M. (1999). The use of crying over spilled milk: A note on the rationality and functionality of regret. Philosophical Psychology, 12, 325-340.

74. Zeelenberg, M. and Pieters, R. (2004), "Beyond valence in customer dissatisfaction: a review and new findings on behavioral responses to regret and disappointment in failed services," Journal of Business Research, Vol. 57 No. 4, pp. 445-455.

75. Zeelenberg, M., \& Pieters, R. (2006). Looking backward with an eye on the future: Propositions toward a theory of regret regulation.

76. Zeelenberg, M., \& Pieters, R. (2007). A theory of regret regulation 1.0. Journal of Consumer Psychology, 17, 3-18.

http://dx.doi.org/10.1207/s15327663jcp1701_3.

77. Zeelenberg, M., Nijstad, B. A., Putten, M. V., \& Dijk, E. V. (2006). Inaction inertia, regret, and valuation: A closer look. Organizational Behavior and Human Decision Processes, 101(1), 89-104. doi: 10.1016/j.obhdp.2005.11.004.

78. Zeelenberg, M., Dijk, V. W., \& Manstead, A. (1998). Reconsidering the Relation between Regret and Responsibility. Organizational Behavior And Human Decision Processes, 74(3), 254-272. doi: 10.1006/obhd.1998.2780.

79. Zeelenberg, M., Dijk, V. W., \& Manstead, A. (2000). Regret and Responsibility Resolved? Evaluating Ordóñez and Connolly's (2000)

Conclusions. Organizational Behavior And Human Decision Processes, 81(1), 143-154. doi: 10.1006/obhd.1999.2865.

80. Zeelenberg, M., Dijk, V. W., Manstead, S. R. A., \& Pligt, D. J. (1998). The Experience of Regret and Disappointment. Cognition And Emotion, 12(2), 221230. doi: 10.1080/026999398379727.

\footnotetext{
${ }^{2 *}$ Corresponding Author

Prof Dr. Zainudin Awang

Corresponding Email

arslan.sarwar@uog.edu.pk
} 